\title{
Agri-Environmental Performance of EU Member states
}

N. Turčeková,T. Svetlanská, B. Kollár, T. Záhorský

Slovak University of Agriculture in Nitra, Slovak Republic

\begin{abstract}
Agriculture as the primary sector has gained increased attention in terms of its environmental implications. Based on the reform of Common Agricultural Policy, there is a link of direct payments to requirements that farmers maintain land in good agricultural and environmental condition and obey the relevant environment legislation since 2003. The aim of our work is the evaluation of agri-environmental performance of 27 European Union member states (we do not consider Croatia as it is the newest member state and there are missing data). We employ data envelopment analysis to calculate environmental efficiency, and Malmquist index for quantification of productivity change with respect of environmental performance. The results show that in terms of agri-environmental efficiency scores Hungary, Malta, Luxembourg and Netherland are the only efficient countries over the whole observed period (2008-2012). The average output-oriented environmental efficiency is found to be 2.4 over the five observed years. The resulting productivity change is an average decrease of TFP (9\%) over the period 2008-2012.
\end{abstract}

\section{Keywords:}

Agri-environmental performance, DEA, efficiency, desirable output, undesirable output.

JEL: Q01, Q53, Q57, C38

Turčeková, N., Svetlanská, T., Kollár, B. and Záhorský, T. (2015) “Agri-environmental Performance of EU member states", AGRIS on-line Papers in Economics and Informatics, Vol. 7, No. 4, pp. 199 - 208, ISSN 1804-1930.

\section{Introduction}

Environmental performance has been lately one of the major global issues. There have been great efforts concentrated on the climate change over the last decades. More recently, agricultural sector and fisheries have gained importance on the global policy agenda in terms of environmental sustainability. Countries are constantly asked to explain their environmental performance on a range of pollution control and natural resource management with reference to quantitative metrics. The aggregated measurement of environmental performance is provided by environmental performance index (EPI), which gives the integrated information for analysts and decision makers dealing with energy and environmental related issues (Esty et al., 2006). The move towards a more data-driven empirical approach to environmental protection enables policymakers to spot problems, track trends, highlight policy successes and failures, identify best practices, and optimize the gains from investments in environmental protection (Emerson et al., 2012). EPI is tool serving to evaluate environmental sustainability. The index considers several policy categories related to environmental public health and ecosystem sustainability. Under the framework of environmental performance evaluation, ecosystem vitality is the objective affected by air pollution, water, biodiversity, forestry, fisheries, agriculture and climate change (Emerson et al., 2012). European agriculture is lately characterized by continuous decrease in the number of farms, while in terms of farm there is a tendency towards larger holdings. It appears that from point of performance efficient countries have big farms and high expenditures for agriculture per agricultural holding and per hectare typical for Netherlands or Denmark or many small family owned farms typical for Mediterranean countries (Svetlanská, Záhorský 2015).

The objective of our work is the evaluation of agri-environmental performance of 27 European Union (EU) member states as there is a lack of studies evaluating agricultural sustainability at regional or national level (Vlontzos et al., 2014). Agri-environmental performance measures on the member states level serves as a tool for evaluating the sustainable development of agriculture in EU. The EU directly supports 
the pro-environmental activities beyond the mandatory measures. Environmental objectives are also included in the new programming period. Therefore, we have built the question of recent development of environmental performance of agriculture in member states. Unlike the EPI, which is the aggregated index, we try to develop an agri-environmental index indicating the environmental performance of European agriculture. We employ greenhouse gas emissions (GGE) from agriculture, labour, arable land, total output of agriculture and fertilizers consumption in evaluation of agri-environmental performance. This paper applies data envelopment analysis (DEA) to calculate the environmental efficiency of member states. This method is used to compare the performance of individual states for its explanatory power. DEA can be applied for the efficiency evaluation of any decisionmaking unit (DMU) that utilizes inputs to produce outputs. The great advantage of DEA is that it allows multiple inputs and outputs enter the model and efficient frontiers of DEA are not defined in functional forms. Furthermore we use Malmquist index to compare the productivity and utilization of factors involved in production over the observed period 2008-2012.

The paper is organized in several chapters. Firstly we briefly depict the theoretical background consisting of literature review related to issue. In the second section we describe the methods and data. Third section is devoted to results and brief conclusion summarizes main findings.

\section{Theoretical background}

Around $40 \%$ of EU land is considered as arable land. Therefore agriculture has a significant influence on the natural environment. Farming and its practices have a significant impact on natural resources, as pollution of soil, water and air, fragmentation of habitats, and a loss of wildlife.

\subsection{Environmental policy in EU - agri-environmental measures}

EU has taken initiative in protecting common environment through the Environment Action Programmes since 1973 (Jordan, 2012). Since 1992, the application of agri-environment programmes and measures have been implemented in all EU states under the framework of their rural development plans (European Commission, 2015). Agri-environmental measures (AEM) became mandatory for all member states after the Agenda 2000, reform of common agricultural policy (CAP) in 1999 (Uthes and Matzdorf, 2013). Based on the reform of CAP there has been a link of direct payments to requirements that farmers maintain land in good agricultural and environmental condition and comply with relevant environment legislation since 2003 (European Commission, 2014). The AEM are integrated in the groups of indicators and proposed by several organizations. Beside the EU and the European Environment Agency (EEA), it is also the Food and Agriculture Organization of the United Nations (FAO), the Organisation for Economic Cooperation and Development (OECD) and the World Commission on Environment and Development (WCED) (Hřebíček et al., 2013).The indicators can be divided into environmental (greenhouse gas emissions from agriculture, water withdrawals, environmental protection expenditures etc.), social (training and education expenditures, health and safety of costumers, etc.), corporate governance (compliance with legal norms, etc.), economic (value added, profitability etc.).

\subsection{Environmental performance}

Environment performance evaluation, EPI, for the most of the countries in the world was introduced in 2006. The EPI is the integrated index which ranks how well countries perform on environmental issues from point of human health and ecosystem (Emerson et al., 2012). Agri-ecosystem is defined according to Swift as "(natural) ecosystems that have been deliberately simplified by people for purpose of the production of specific goods of value to humans"(Swift et al., 2004).

There have been a large collection of wide-ranging environmental indicators constructed and applied by different organizations aimed to calculate environmental performance (Tyteca, 1996, Olsthoom et al., 2001). In order to compose the index there is often used multiple criteria decision making considered as an indirect method (DiazBalteiro and Romero, 2004). In case of indirect method there is a need to normalize indicators in a first stage of constructing the indicator. The direct approach incorporates the pollutants as undesirable output in the productive efficiency of agriculture. Productive efficiency measurement was pioneered by Pittman (1983), who extended the CCD multilateral productivity index (Caves et al., 1982) and took undesirable outputs into consideration. One limitation of Pittman's work is that it requires the prices of pollutants which are difficult to measure (Zhou et al. 2006).

Another measure is based on Coelli's et al. (2007) 
environmental efficiency. The environmental efficiency incorporates material balance condition into production models (Turčeková et al., 2015). Material balance condition can be explained by the balance of nutrients and thus the difference between nutrients in inputs and nutrients in outputs. Popular method recently used to measure environmental performance is the data envelopment analysis (DEA), which only requires the observed quantities of inputs and outputs. DEA is widely used to calculate technical efficiency of energy industry (Boyd and Pang, 2000; Ramanathan, 2000) and ecological efficiency (Dyckhoff and Allen, 2001; Korhonen and Luptacik, 2004, Hassan, 2014). Sustainability efficiency of agriculture of OECD countries was estimated by Hoang and Rao (2010).

The application of DEA aimed to measure environmental performance is built upon the fact that outputs are divided into desirable and undesirable outputs (Scheel, 2001). Traditional DEA models mainly handle desirable outputs that have the property of 'the more the better', while the undesirable outputs have the property 'the less the better'.

The use of DEA in environmental efficiency evaluation has been steadily increasing after 2000. There are different extensions of DEA models taking into account the undesirable outputs of the production process (Vlontzos et al., 2014). Based on the efficiency measures we distinguish radial and non-radial DEA. In the radial type of efficiency measures inputs and outputs are adjusted proportionally, while in non-radial the adjustments can be non-proportional (Sueyoushi and Goto, 2012). Wang et al. (2013) decomposed efficiency of agricultural production in 29 Chinese regions to three basic elements: technical efficiency, economical efficiency and environmental efficiency, using DEA window analysis.

\section{Materials and methods}

In the paper we apply radial output-oriented DEA to measure environmental efficiency. Then, based on the efficiency results we compute Malmquist indices to measure the change in total factor productivity. For the efficiency measurement we use R software 3.1.0. Additional computations are done in Microsoft Office Excel.

\section{Data}

Model works with one desirable output - total agricultural output (TAO) in million EUR (EUROSTAT, 2015a) adjusted by Harmonised
Index of Consumer Prices (HICP) basis of year 2012(EUROSTAT, 2015b).In this paper the panel data is used. Therefore the variables expressed in currency units are adjusted. Firstly TAO inflation adjustment to the prices of the year 2012 is done through HICP. Consequently, the adjusted TAO is adapted by Purchasing Power Parity (PPP) for the year 2012 so that EU28 $=1$ (EUROSTAT, 2015c). HICP unifies the time aspect to 2012 basis and consequently purchasing power across the countries are adapted to the EU average for each year on the basis of 2012 .

We include one undesirable output - greenhouse gas emissions (GGE) in 1000 tonnes of $\mathrm{CO}_{2}$ equivalent (EUROSTAT, 2015d). These outputs are produced as a result of set of inputs. We consider arable land in hectares (AREA)(EUROSTAT, 2015e), labour force (LAB) in 1000 annual work units (EUROSTAT, 2015f), fertilizers consumption in tonnes (NFERT - nitrogenous fertilizers, PFERT - potassium fertilizers) (EUROSTAT, 2015g) and agricultural subsidies (SUB) in million EUR (EUROSTAT, 2015h). Subsidies were adjusted in the same way as TAO (using HICP and subsequently by PPP) (Table 1).

\section{Data envelopment analysis}

The employment of DEA models enable to measure efficiency involving multiple inputs and outputs. It is based on seminal work of Farrell (1957) and it is a non-parametric approach toward efficiency measurement using linear programming, accounting for multiple outputs and inputs. These models can be constructed either as output oriented (maximization) or input oriented (minimization). We employ output-oriented model which answer the question by how much can output quantities be proportionally expanded without altering the input quantities (Coelli, 2005).We calculate the radial DEA, which is based on proportional reduction of undesirable output. The advantage of using the radial DEA is in its explanatory power and enables clear interpretation of efficiency scores. Use of input or output oriented model provide similar values under constant return to scale (CRS) but are unequal when variable return to scale (VRS) is assumed.

In the case of environmental efficiency we employ output-oriented model with CRS in form:

$$
\begin{gathered}
\max _{\varphi, \lambda) \varphi}, \\
\text { st- } \varphi y_{i}+Y \lambda \geq 0 \\
x_{i}-X \lambda \geq 0 \\
\lambda \geq 0
\end{gathered}
$$




\begin{tabular}{|c|c|c|c|c|c|}
\hline Year & Variable & Mean & Std. Dev. & Min & Max \\
\hline \multirow[t]{7}{*}{2008} & TAO & 10920.29 & 16464.46 & 30.05 & 58367.76 \\
\hline & GGE & 78.93 & 23.54 & 1.00 & 96.84 \\
\hline & SUB & 1683.96 & 2469.96 & 4.12 & 8626.72 \\
\hline & NFERT & 399003.70 & 579507.70 & 300.00 & 2425200.00 \\
\hline & PFERT & 44733.33 & 67626.89 & 100.00 & 282400.00 \\
\hline & LAB & 425.39 & 606.18 & 3.70 & 2299.30 \\
\hline & AREA & 4042293.00 & 4795399.00 & 8000.00 & 18300000.00 \\
\hline \multirow[t]{7}{*}{2009} & TAO & 9658.58 & 14761.72 & 22.03 & 53083.61 \\
\hline & GGE & 79.36 & 22.85 & 4.42 & 96.85 \\
\hline & SUB & 1644.04 & 2389.20 & 4.86 & 8468.53 \\
\hline & NFERT & 367629.60 & 511292.00 & 400.00 & 2098800.00 \\
\hline & PFERT & 32596.30 & 45939.84 & 0.00 & 163900.00 \\
\hline & LAB & 414.03 & 591.49 & 3.60 & 2213.80 \\
\hline & AREA & 4035084.00 & 4781721.00 & 8000.00 & 18300000.00 \\
\hline \multirow[t]{7}{*}{2010} & TAO & 10470.85 & 15902.43 & 23.53 & 57839.56 \\
\hline & GGE & 79.45 & 22.66 & 5.24 & 96.85 \\
\hline & SUB & 1708.65 & 2473.03 & 5.94 & 8742.59 \\
\hline & NFERT & 381103.70 & 513359.10 & 400.00 & 2080000.00 \\
\hline & PFERT & 38170.37 & 51480.38 & 0.00 & 177000.00 \\
\hline & LAB & 375.56 & 504.63 & 3.70 & 1914.80 \\
\hline & AREA & 3979176.00 & 4695259.00 & 9000.00 & 18400000.00 \\
\hline \multirow[t]{7}{*}{2011} & TAO & 11587.70 & 17420.15 & 31.07 & 62947.06 \\
\hline & GGE & 79.42 & 22.94 & 4.05 & 96.86 \\
\hline & SUB & 1730.63 & 2489.59 & 6.56 & 8806.72 \\
\hline & NFERT & 392759.30 & 568736.80 & 0.00 & 2332400.00 \\
\hline & PFERT & 40851.85 & 60350.72 & 0.00 & 218400.00 \\
\hline & LAB & 365.74 & 489.57 & 3.70 & 1914.80 \\
\hline & AREA & 3979880.00 & 4695029.00 & 9000.00 & 18400000.00 \\
\hline \multirow[t]{7}{*}{2012} & TAO & 12425.06 & 18702.11 & 31.23 & 68555.20 \\
\hline & GGE & 79.63 & 22.37 & 7.66 & 96.86 \\
\hline & SUB & 1805.15 & 2556.13 & 7.28 & 9044.98 \\
\hline & NFERT & 376555.60 & 514572.80 & 0.00 & 2024700.00 \\
\hline & PFERT & 39074.07 & 54823.03 & 0.00 & 189600.00 \\
\hline & LAB & 363.65 & 490.33 & 3.80 & 1914.90 \\
\hline & AREA & 3980343.00 & 4665489.00 & 9000.00 & 18300000.00 \\
\hline
\end{tabular}

Source: own processing based on EUROSTAT data

Table 1: Descriptive statistics of data.

where $\varphi$ is efficiency rate for each decisionmaking unit (DMU, EU member states in this case), $\lambda$ refer to linear combination of inputs and outputs, $\mathrm{Y}$ is vector of outputs and $\mathrm{X}$ vector of inputs. The condition $\lambda \geq 0$ indicates CRS. In case of environmental efficiency it is essential to classify inputs and outputs into desirable and undesirable. The aim is to reduce undesirable outputs and maximize desirable outputs.

Efficiency measures obtained from the output oriented DEA imply that the output of the given DMU (country in this case) should be multiply by the efficiency measure in order for the unit to become efficient. Given that the inputs of the unit remain stable. When the undesirable output (such as greenhouse gas emission) is present, it needs to be adjusted. Procedure applied in this paper is as follows:

$$
\begin{aligned}
\text { Adjusted value }= & {[\operatorname{Max}(G G E)+1] } \\
& - \text { Actual GGE }(\text { country/year })
\end{aligned}
$$


We have chosen the maximum of the GGE for the whole studied period in order to capture the possible change for the country with maximum of the GGE. If the maximum for the given year would be chosen, there could be a situation in which the particular country would have maximum for every year and no change in the amount of the GGE would be observable for this country.

\section{Malmquist index, distance functions}

Malmquist index is used to compare the development of environmental performance over the time periods 2008-2012. It is the measure of total factor productivity (TFP) change and it decomposes this productivity change into technical change and technical efficiency change (Coelli, 2005).Malmquist index is the geometric mean of 2 production function involving technical efficiency change (TECH) and technological change (TCH).

Malmquist index is a geometric mean of two production functions based on the distance functions. The distance function based approach for measuring the TFP seeks to separate TFP into two components. This is done using an output distance function that measures the distance of DMU from its production function. In principle, this technique enables a change in TFP to be decomposed into changes resulting from a movement towards the production frontier and shifts in the frontier. The output distance function measures how close a particular output vector is to the production frontier given a particular input vector (Mawson, 2003).

$$
\begin{aligned}
M_{o}\left(y_{t+1}, x_{t+1}, y_{t}, x_{t}\right) & = \\
& {\left[\frac{d_{0}^{t}\left(y_{t+1}, x_{t+1}\right)}{d_{0}^{t}\left(y_{t}, x_{t}\right)} \times \frac{d_{0}^{t+1}\left(y_{t+1}, x_{t+1}\right)}{d_{0}^{t+1}\left(y_{t}, x_{t}\right)}\right]^{1 / 2} }
\end{aligned}
$$

which can be further adjusted to:

$$
\begin{aligned}
& M_{o}\left(y_{t+1}, x_{t+1}, y_{t}, x_{t}\right)=\frac{d_{0}^{t+1}\left(y_{t+1}, x_{t+1}\right)}{d_{0}^{t}\left(y_{t}, x_{t}\right)} \\
& \times\left[\frac{d_{0}^{t}\left(y_{t+1}, x_{t+1}\right)}{d_{0}^{t+1}\left(y_{t+1}, x_{t+1}\right)} \times \frac{d_{0}^{t}\left(y_{t}, x_{t}\right)}{d_{0}^{t+1}\left(y_{t}, x_{t}\right)}\right]^{1 / 2}
\end{aligned}
$$

where $y_{t}, x_{t}$ are output and input in the basic period, $y_{(t+1)}, x_{(t+1)}$ are output and input in the next period. Notation $d_{0}{ }^{t}$ and $d_{0}{ }^{(t+1)}$ represents distance of the DMU in the basic and next period. The resulting product of Malmquist index $\left(M_{o}\right)$ is change in productivity. It includes change of technical efficiency (TECH) and technological change (TCH). Whenever the $M_{o}>1$ it signalizes the enhanced productivity. TECH $>1$ indicates the enhanced TE, while $\mathrm{TCH}>1$ represents technological progress.

\section{Results and discussion}

\section{Environmental efficiency}

The radial DEA is applied to calculate environmental efficiency of 27 countries of EU from 2008 to 2012. As in this case the environmental efficiency has the same properties as technical efficiency the effective states lie on the production possibility frontier and have the value of one (Table 2). From the table it is clear that Hungary, Luxembourg, Malta and Netherlands are efficient over the observed period. In case of Hungary there are low GGE over whole observed period $\left(\overline{8.79} / 1000 \mathrm{t}\right.$ of $\left.\mathrm{CO}_{2} \mathrm{eq}\right)$. In general, considered the amount of arable agricultural land (4491000 ha in average) and the share of agriculture on GDP (4.08\%), Hungary belongs to leading group in terms of agri-environmental performance. On the other hand Netherlands has lower amount of arable land (1048916.67 ha in average) but has higher GGE ( $\overline{16.48} / 1000 \mathrm{t}$ of $\mathrm{CO}_{2}$ eq). However we can observe lower consumption of fertilizers, labour and higher support in form of subsidies. The Netherlands signals some positive outcomes from environmental policies under which the nitrogen and phosphorous surpluses exceeding certain limits were subject to levies (Hoang, 2010). In terms of TAO, Netherlands had the highest output over the observed period. Luxembourg has among the observed states one of the least number of agricultural holdings, thus agriculture accounts for only a small percentage of GDP $(0.3 \%)$. It can be therefore assumed that the sector of agriculture is not the major producer of pollution in Luxembourg which is also proved by low GGE $\left(\overline{0.68} / 1000 \mathrm{t}\right.$ of $\mathrm{CO}_{2}$ eq). Malta as an island state is one of the smallest countries of EU yet sector of agriculture is quite diverse. The share of agriculture on GDP (1.7\%) together with low consumption of fertilizers and labour lead to low GGE $\left(\overline{0.09} / 1000\right.$ t of $\mathrm{CO}_{2}$ eq $)$.

The countries, with efficiency scores higher than one, should either expand their desirable output (TAO) or reduce the undesirable output (GGE). With the mean efficiency 2.4 over the five observed years, an average EU member state should augment the TAO and reduce GGE approximately two and half time given the current inputs. Vlontzos et al. (2014) applied DEA approach for agricultural environmental efficiency of EU countries for period 2001-2008. Conclusions suggested that countries 


\begin{tabular}{|l|c|c|c|c|c|c|}
\hline Country/Year & eff_2008 & eff_2009 & eff_2010 & eff_2011 & eff_2012 & mean_eff \\
\hline Austria & 2.59 & 2.35 & 2.75 & 3.24 & 3.42 & 2.55 \\
\hline Belgium & 1.38 & 1.37 & 1.52 & 1.00 & 1.00 & 1.38 \\
\hline Bulgaria & 3.71 & 3.55 & 4.28 & 4.01 & 4.66 & 4.04 \\
\hline Cyprus & 1.03 & 1.27 & 1.20 & 1.38 & 1.47 & 1.17 \\
\hline Czech Republic & 1.42 & 2.55 & 2.85 & 2.82 & 2.93 & 2.52 \\
\hline Denmark & 2.03 & 2.17 & 2.08 & 1.99 & 1.85 & 2.02 \\
\hline Estonia & 3.03 & 3.95 & 3.34 & 2.91 & 2.76 & 3.20 \\
\hline Finland & 3.76 & 3.64 & 4.08 & 3.64 & 3.55 & 3.73 \\
\hline France & 1.91 & 1.90 & 2.27 & 2.12 & 2.10 & 2.06 \\
\hline Germany & 1.67 & 1.78 & 2.16 & 1.82 & 1.89 & 1.86 \\
\hline Greece & 2.53 & 2.98 & 2.97 & 3.81 & 4.28 & 2.85 \\
\hline Hungary & 1.00 & 1.00 & 1.00 & 1.00 & 1.00 & 1.00 \\
\hline Ireland & 3.79 & 4.32 & 5.02 & 4.64 & 4.82 & 4.52 \\
\hline Italy & 1.78 & 1.92 & 2.05 & 2.37 & 2.49 & 1.95 \\
\hline Latvia & 5.66 & 4.77 & 5.16 & 5.19 & 4.74 & 5.11 \\
\hline Lithuania & 3.84 & 4.88 & 5.50 & 4.91 & 4.91 & 4.81 \\
\hline Luxembourg & 1.00 & 1.00 & 1.00 & 1.00 & 1.00 & 1.00 \\
\hline Malta & 1.00 & 1.00 & 1.00 & 1.00 & 1.00 & 1.00 \\
\hline Netherlands & 1.00 & 1.00 & 1.00 & 1.00 & 1.00 & 1.00 \\
\hline Poland & 3.55 & 4.13 & 4.44 & 4.61 & 5.13 & 4.37 \\
\hline Portugal & 2.19 & 2.45 & 2.36 & 2.59 & 3.03 & 2.36 \\
\hline Romania & 2.12 & 3.11 & 3.15 & 3.02 & 4.42 & 3.16 \\
\hline Slovakia & 3.93 & 4.74 & 3.97 & 3.53 & 3.59 & 3.95 \\
\hline Slovenia & 2.63 & 3.23 & 3.31 & 2.96 & 3.46 & 3.09 \\
\hline Spain & 2.17 & 2.34 & 2.89 & 3.36 & 3.44 & 2.55 \\
\hline Sweden & 2.47 & 3.45 & 3.19 & 3.01 & 2.83 & 2.99 \\
\hline United Kingdom & 1.53 & 1.63 & 1.98 & 1.68 & 1.61 & 1.68 \\
\hline & & & & & & 2 \\
\hline
\end{tabular}

Notes: eff denotes the efficiency scores, mean_eff denotes average efficiency scores for the period 2008-2012 Source: own processing based on EUROSTAT data

Table 2: Environmental efficiency scores.

like Germany, Sweden, or Austria, with strong environmental protection standards, appear to be less environmentally efficient in the field of primary sector. Calculated environmental efficiencies over the period 2008-2012 confirm these results as well as the conclusion that a series of eastern European countries achieve low efficiency scores. Slovakia, the Czech Republic and Poland are among the countries with highest efficiency scores (what indicate a low efficiency in case of output-oriented model), due to low level of technology used in agriculture. The low environmental performance in eastern European countries also suggests extensive use of fertilizers as the remaining of intensive agricultural practises. On the other hand there are differences on the efficient states. Hungary, Malta, Luxembourg and Netherlands (in case of Vlontzos et al. work it is Belgium, Bulgaria, Denmark, Italy, Netherlands and Spain) are efficient over whole observed period of 2008-2012. This is due to low GGE levels - undesirable output - decreasing over the observed period. Another key factors playing role are CAP subsidies that can increase TE or environmental efficiency if they provide an incentive to innovate or switch to new technologies (Harris and Trainor, 2005) confirmed by the example of Hungary, where the high subsidies, low emissions and favourable conditions assign it to the most efficient member states. The fact that the environmental performance of agriculture over the compared period 20012008 (Vlontzos et al., 2014) and presented results for the period 2008-2012 did not change significantly indicates that new subsidy management scheme has not motivated further improvement of environmental efficiency, despite the fact that this was one of the most important goals of the CAP. 
Among the survey of environmental and sustainable efficiency in 29 OECD countries the Netherlands, Luxembourg and Denmark were found as the most sustainable systems in work of Hoang and Rao (2010). They decomposed the sustainable efficiency into technical efficiency and exergy allocative efficiency, using non-parametric DEA. However, based on obtained results Denmark in order to be more environmentally efficient, should increase output with respect of given inputs, which are characterized by relatively high consumption of fertilizers. In this case the GGE are relatively low $\left(\overline{9.72} / 1000\right.$ t of $\left.\mathrm{CO}_{2} \mathrm{eq}\right)$.

\section{Total factor productivity change}

Table 3 shows the results of total factor productivity (TFP) change - Mamlquist index, representing the increase or decrease in productivity. Values greater than 1 indicate better use of inputs resulting in increase of TAO or reduction of GGE (as undesirable output). The average value over the observed period is 0.91 implying decrease in productivity. On average, EU countries experienced aTFP decrease in rate of $9 \%$. This decrease was caused by the technological regress (index 0.93). The technical efficiency scores representing the environmental performance of EU states did not change in average over the observed period (average index 1.00).

Nine European countries experienced the improved technical efficiency (TE) over the observed period
(Table 3) in average growth rate of $14 \%$, namely Bulgaria, Denmark, France, Greece, Ireland, Latvia, Portugal, Romania and Spain. TE of the rest of the countries declined or stayed unchanged (in case of Austria, Germany, Luxembourg, Malta, the Netherlands and Slovenia). Table 3 also shows the decomposition of TFP (Malmquist index) into technical efficiency change (TECH) and technological change (TCH). On average, there was a technological regress over the observed period of $7 \%$ in terms of environmental performance among the EU states. However, after year 2010 there was a technological progress in almost all countries (except of the Czech Republic, Hungary and Sweden). Technological progress result into decrease of GGE.

Domanska et al. (2014) studied the TFP of agriculture in EU states over the period of 2007-2011, finding the small increase $(2.4 \%)$ mainly caused by TE improvements. When we consider the environmental indicators and GGE, TE improvements of agriculture are neglected, due to the environmental pressure. Farming businesses in EU countries could improve their environmental performance by changing the use of inputs and changing the structure of farming management practices (Hoang, 2010). All of these findings support the demand for comprehensive evaluations of the implementation of the agro-environmental policies.

\begin{tabular}{|l|c|c|c|l|c|c|c|}
\hline Country/Indicator & TECH & TCH & TFP & Country/Indicator & TECH & TCH & TFP \\
\hline Austria & 1.00 & 1.06 & 1.06 & Latvia & 1.36 & 0.72 & 0.98 \\
\hline Belgium & 0.98 & 1.06 & 1.03 & Lithuania & 0.99 & 1.00 & 0.99 \\
\hline Bulgaria & 1.36 & 0.62 & 0.85 & Luxembourg & 1.00 & 1.01 & 1.01 \\
\hline Cyprus & 0.90 & 0.94 & 0.84 & Malta & 1.00 & 0.79 & 0.79 \\
\hline Czech Republic & 0.69 & 0.65 & 0.45 & Netherlands & 1.00 & 1.16 & 1.16 \\
\hline Denmark & 1.13 & 0.69 & 0.78 & Poland & 0.86 & 0.82 & 0.71 \\
\hline Estonia & 0.93 & 0.98 & 0.91 & Portugal & 1.02 & 1.05 & 1.08 \\
\hline Finland & 0.96 & 1.06 & 1.02 & Romania & 1.35 & 0.52 & 0.71 \\
\hline France & 1.01 & 1.07 & 1.08 & Slovakia & 0.94 & 1.04 & 0.97 \\
\hline Germany & 1.00 & 1.07 & 1.08 & Slovenia & 1.00 & 1.02 & 1.02 \\
\hline Greece & 1.02 & 1.06 & 1.08 & Spain & 1.02 & 1.06 & 1.08 \\
\hline Hungary & 0.75 & 0.70 & 0.52 & Sweden & 0.82 & 0.86 & 0.71 \\
\hline Ireland & 1.04 & 1.06 & 1.10 & United Kingdom & 0.98 & 1.07 & 1.05 \\
\hline Italy & 0.97 & 1.05 & 1.02 & EU-27 & 1.00 & 0.93 & 0.91 \\
\hline
\end{tabular}

Notes: TECH, TCH, TFP - geometric mean over the period 2008-2012

Source: own processing 


\section{Conclusion}

The aim of this paper was to evaluate the environmental performance of agriculture in 27 EU member states (we do not consider Croatia as it is the newest member state and there are missing data). We employed radial output-oriented DEA model to calculate environmental efficiency. The model enabled to involve desirable output of TAO which was maximized and undesirable output of GGE which was minimized. We can conclude that only four countries (Hungary, Luxembourg, Malta and Netherlands) reached the value of one, thus were efficient over the whole observed period of 2008-2012. The average environmental efficiency of 2.4 over the five observed years suggests that an average EU member state should augment the TAO and reduce GGE two and half time given the current inputs. Efficiency is greatly influenced by consumption of inputs. Extensive use of fertilizers led to higher GGE, but it is vital to take arable land into account as extensive utilised agriculture area requires higher input of fertilizers and labour. It can be also concluded that subsidy management has not motivated further improvement of environmental efficiency, thus there is a need to increase the effectiveness of agro-environmental policies. The Malmquist index was used to measure the change of TFP over the observed period in EU member states. The average decrease of TFP (9\%) was observed over 2008-2012. This decrease was caused by the average technological regress. However after the year 2010 almost all countries improved technology. Improved technology in case of environmental performance evaluation indicates decrease in GGE.

The empirical results showed that agriculture is the sector with largest remaining environmental mitigation potential with respect to its resources. Environmental adaptation of European agriculture depends on the capacities of farming businesses across the Europe to manage the use of input mixes in sustainable and environmental friendly way.

\section{Corresponding author:}

doc. Ing. Natália Turčeková, PhD.

Faculty of Economics and Management, Slovak University of Agriculture in Nitra,

Tr. Andreja Hlinku 2, 94976 Nitra, Slovak Republic

E-mail:natalia.turcekova@uniag.sk

\section{References}

[1] Boyd, G. A., Pang, J. X. Estimating the linkage between nnergy efficiency and productivity .Energy Policy. 2000, Vol. 28, No. 5, p. 289-296. ISSN 0301-4215.

[2] Caves, D. W., Christensen, L. R., Diewert, W. E. Multilateral comparisons of output, input and productivity using superlative index numbers. The Economic Journal. 1982, Vol. 92, No. 365, p. 73-86. ISSN 1468-0297

[3] Coelli, T. J., Lauwers, L.,Van Huylenbroeck, G. Environmental Efficiency Measurement and the Materials Balance Condition. Journal of Productivity Analysis. 2007, Vol. 28, No. 1, p.3-12. ISSN 1573-0441.

[4] Diaz-Balteiro, L., Romero, C. In search of a natural systems sustainability index. Ecological Economics. 2004, Vol. 49, No. 3, p. 401-405. ISSN 0921-8009.

[5] Domanska, K., Kijek, T., Nowak, A. Agricultural Total Factor Productivity Change and its Determinants in European Union Countries. Bulgarian Journal of Agricultural Science. 2014. Vol. 20, No.6, p. 273-1280. ISSN1273-1280.

[6] Dyckhoff, H., Allen, K. Measuring ecological efficiency with data envelopment analysis (DEA). European Journal of Operational Research. 2001, Vol. 132, No. 3, p. 312-325. ISSN 0377-2217.

[7] Emerson, J. W., Hsu, A., Levy, M. A., De Sherbinin, A., Mara, V., Esty, D.C., Jaiteh, M. 2012 Environmental Performance Index and Pilot Trend Environmental Performance Index. New Haven: Yale Center for Environmental Law and Policy. 2012 [Online] Available: http://epi.yale.edu/ files/2012_epi_report.pdf [Accessed: 15 March 2015]. 
[8] Esty, D. C., Levy, M. A., Srebotnja, T., De Sherbinin, A., Kim,B., Anderson, B. Pilot Environmental Performance Index. Yale Centre for Environmental Law \& Policy, NewHaven. 2006 [Online]. Available: http://epi.yale.edu/files/2006_pilot_epi_report.pdf [Accessed: 15 March 2015].

[9] European Comission. General Union Environment Action Programme to 2020. 2012/0337 (COD). 2014.A7-0166/2013, [Online] Available: http://www.europarl.europa.eu [Accessed: 20 April 2015].

[10] Eurostat (2015a). Output of the agricultural industry - basic and producer prices (tag00102). [Online] Available: http://ec.europa.eu/eurostat/tgm/table. do?tab=table\&init=1\&language $=$ en\&pcode $=\operatorname{tag} 00102 \&$ plugin $=1$. (Last data update 18. 11. 2015) [Accessed: 20 November 2015].

[11] Eurostat $(2015 b)$. HICP $(2005=100)$ - annual data (average index and rate of change) (prc_hicp_ aind). [Online] Available: http://appsso.eurostat.ec.europa.eu/nui/show.do?dataset=prc_hicp_ aind\&lang=en. (Last data update 16. 11. 2015) [Accessed: 20 November 2015].

[12] Eurostat (2015c). Purchasing power parities (PPPs), price level indices and real expenditure sfor ESA2010 aggregates (prc_ppp_ind). [Online] Available: http://appsso.eurostat.ec.europa.eu/nui/ show.do?dataset=prc_ppp_ind\&lang=en . (Last data update 18. 9. 2015) [Accessed: 10 October 2015].

[13] Eurostat (2015d). Greenhouse gas emissions by sector (source: EEA) (tsdec210). [online] Available: http://ec.europa.eu/eurostat/tgm/refreshTableAction.do?tab=table\&plugin=1\&pcode $=$ tsdcc210\&language $=$ en . (Last data update 02. 07. 2015) [Accessed: 10 October 2015].

[14] Eurostat (2015e). Arable crops: number of farms and areas of different arable crops by economic size of farm (SO in Euro) and size of arable area (ef_alarableecs). [Online] Available: http://appsso. eurostat.ec.europa.eu/nui/show.do?dataset=ef_alarableecs\&lang=en. (Last data update 18. 11.2015) [Accessed: 20 November 2015].

[15] Eurostat (2015f). Agricultural Labour Input Statistics: absolute figures (1 000 annual work units) (aact_ali01). [On-line] Available: http://appsso.eurostat.ec.europa.eu/nui/show.do?dataset=aact_ ali01\&lang=en . (Last data update 18. 11. 2015) [Accessed: 20 November 2015].

[16] Eurostat $(2015 \mathrm{~g})$. Consumption estimate of manufactured fertilizers (source: Fertilizers Europe) (aei_fm_manfert). [Online] Available: http://ec.europa.eu/eurostat/tgm/table. do? tab $=$ table \&init $=1 \&$ language $=$ en $\& p \operatorname{pode}=\operatorname{tag} 00090 \&$ plugin $=1$. (Last data update 17. 12. 2014) [Accessed: 15 March 2015].

[17] Eurostat (2015h). Economic accounts for agriculture - values at current prices (aact_eaa01). [Online] Available: http://appsso.eurostat.ec.europa.eu/nui/show.do?dataset=aact_eaa01\&lang=en. (Last data update 18. 11. 2015) [Accessed: 20 November 2015].

[18] Harris, R., Trainor M. Capital subsidies and their impact on total factor productivity: Firm-level evidence from Northern Ireland. Journal of Regional Science. 2005. Vol. 45, No.1, p.49-74. ISSN: 1467-9787.

[19] Hassan, F. M., Salman, J. M. Alkam, F. A., Jawad, H. Ecological Observations on Epipelic Algae in Euphrates River at Hindiya and Manathira, Iraq. International Journal of Advanced Research. 2014, Vol. 2, No. 4, p. 1183-1194, ISSN 2320 - 5407.

[20] Hoang, V.N. Measuring and decomposing changes in agricultural productivity, nitrogen use efficiency and cumulative exergy efficiency: Application to OECD agriculture. Ecological Modelling. 2010. Vol. 222, No. 1, p. 164-175. ISSN 0304-3800.

[21] Hoang, V. N., Rao, P. Measuring and decomposing sustainable efficiency in agricultural production: A cumulative exergy balance approach. Ecological Economics. 2010. Vol. 69, No. 9, p. 1765-1776. ISSN 0921-8009.

[22] Jordan, A. J., Adelle, C. Environmental Policy in the European Union: Contexts, Actors and Policy Dynamics (3ed). Earthscan: London and Sterling. 2012, [Online] Available: https://www.book2look. com/embed/9781136272202 [Accessed: 15 March 2015]. 
[23] Korhonen, P. J., Luptacik, M. Eco-efficiency analysis ofpower plants: An extension of data envelopment analysis. European Journal of Operational Research. 2004, Vol. 154, No. 2, p. 437-446. ISSN 0377-2217.

[24] Mawson, P. Productivity measurement: Alternative approaches and estimates. New Zealand Treasury Working Paper. 2003. Working paper 03/12, p. 9-10. Treasury:494653v4.

[25] Olsthooml, X., Tyteca, D., Wehrmeyer, W., Wagner, M. Environmental indicators for business: A review of the literature and standardisation methods. Journal of Cleaner Production. 2001, Vol. 9 , No. 5, p. 453-463. ISSN 0959-6526.

[26] Ramanathan, R. A holistic approach to compare energy efficiencies of different transport models. Energy Policy. 2000, Vol. 28, No. 11, p.743-747. ISSN 0301-4215.

[27] Scheel, H. Undesirable outputs inefficiency valuations, European Journal of Operational Research. 2001, Vol. 132, No. 2, p. 400-410. ISSN 0377-2217.

[28] Swift, M. J., Izac, A.-M. N., Van Noordwijk, M. Biodiversity and ecosystem services in agricultural landscapes - are we asking the right questions. Agriculture, Ecosystems and Environment. 2004, Vol. 104, No.1, p.113-134. DOI: doi:10.1016/j.agee.2004.01.013. ISSN: 0167-8809.

[29] Hřebíček, J., Valtinyová, S., Křen, J. Hodinka, M., Trenz, O., Marada. P. Sustainability Indicators: Development and Application for the Agriculture Sector. In Marina G Erechtchoukova, Peter A Khaiter, Paulina Golinska. Sustainability Appraisal: Quantitative Methods and Mathematical Techniques for Environmental Performance Evaluation. Heidelberg: Springer-Verlag, 2013. p. 63-102, 40 p., EcoProduction. doi:10.1007/978-3-642-32081-1. ISBN 978-3-642-32080-4.

[30] Turčeková N., Svetlanská T., Adamičková I. Efficiency Of Biomass Production - Methodological Approaches. Visegrad Journal on Bioeconomy and Sustainable Development. 2015, Vol. 4, No. 1, p. 2-6. DOI: 10.1515/vjbsd-2015-0001. ISSN 1339-3367.

[31] Svetlanská, T., Záhorský, T. Technical efficiency and productivity of agriculture in EU member states. In Scientia Iuventa 2015. Banská Bystrica: Belianum, 2015, p. 553-561. ISBN 978-80-557-0858-4.

[32] Sueyoshi T., Goto M. Data envelopment analysis for environmental assessment: comparison between public and priváte ownership in petroleum industry. 2012. European Journal of Operational Research. Vol. 216, No. 3, p. 668-678. DOI: 10.1016/j.ejor.2011.07.046. ISSN: 0377-2217.

[33] Tryon, R. C. Cluster Analysis. Ann Arbor, MI: EdwardsBrothers. 1939.

[34] Tyteca, D. On the measurement of the environmental performance of firms - a literature review and a productive efficiency perspective. Journal of Environmental Management. 1996, Vol. 46, No. 3, p. 281-308. ISSN 0301-4797.

[35] Uthes, S., Matzdorf, B. Studies on Agri-environmental Measures: A Survey of the Literature. Environmental Management. 2013, Vol. 51, No. 1, p. 251-266. ISSN 1432-1009.

[36] Vlontzos, G., Nyavis S., Manos, B. A DEA approach for estimating the agricultural energy and environmental efficiency of EU countries. Renewable and Sustainable Energy Reviews. 2014. Vol. 40., p. 91-96. ISSN 1364-0321.

[37] Zhou, P., Ang, B. W., Poh, K. L. Slacks-based efficiency measures for modeling environmental performance. Ecological Economics. 2006, Vol. 60, No. 1, p. 111-118. doi:10.1016/j.ecolecon.2005.12.001. ISSN 0921-8009. 